\title{
Priority of the Federal Tax Lien
}

William $F$. Young, $J$ r.

An act of magnanimity on the part of the United States government is worthy to be celebrated. Therefore we should greet the Federal Tax Lien Act of $1966^{1}$ with at least a faint hurrah. A major part of this act is designed to trim the government's power to collect tax claims, and to show a decent regard to the competing claims and interests of others who have dealings with the taxpayer.

There was a time when the government could frustrate a perfectly ordinary sale or mortgage of the taxpayer's property by virtue of an unpublished statutory lien. However, Congress has acted several times to dilute this claim. ${ }^{2}$ The statutory deposit existing prior to the Act of 1966 was section 6323 of the Internal Revenue Code of 1954, as amended, containing five rather short subsections. The newly amended section $6323^{3}$ contains nine subsections, including some longer than the old 6323 was in its entirety, and it is fitted out with definitions, limitations, and "special rules." The amendment constitutes an enormous outcropping of new federal concepts. It needs a chart to venture into the recesses. This paper will, at best, mark some of the main paths and dead-ends, leaving much to be explored.4

William F. Young, Jr., Professor of Law, Columbia University, received a B.A. degree in 1947 and an LL.B. degree in 1949 from the University of Texas.

1 Public Law 89-719 (November 2, 1966), amending certain sections of the Internal Revenue Code of 1954. The Act climaxed a decade of effort by the American Bar Association to gain greater recognition for secured interests. The Treasury had blocked previous moves, and negotiated actively for its interest in the process of drafting the Act.

The Act is analyzed in Plumb \& Wrighr, Federal TAx LIENS (2d ed. 1967) [hereinafter cited as Plumb \& WRIGHT]. Brief explanations have been published in various journals as follows: Creedon, The Federal Tax Lien Act of 1966-An Historic Breakthrough, 4 HaRv. J. Lecrs. 163 (1967); Plumb, The New Federal Tax Lien Law, 53 A.B.A.J. 66 (1967); What the Banker Should Know About Federal Tax Liens and Levies-Revisited, 54 BANKING L.J. 1 (1967); Plumb, The New Federal Tax Lien Law, 22 Bus. LAw. 271 (1967); Williams \& Plumb, The Federal Tax Lien Act of 1966, 44 TAXes 933 (1966).

2 In 1913 magnanimity was shown to mortgagees, purchasers, and judgment creditors by making the federal tax lien invalid as to them unless a notice of lien was filed in a designated public office. Act of March 4, 1913, ch. 166, 37 Stat. 1016. Congress later added "pledgees" to the protected classes. Act of June 29, 1939, ch. 247, § 401, 53 Stat. 882 (1939).

3 INT. REv. CoDE of 1954, $\$ 6323$, as amended by 80 Stat. 1125 (1966).

4 Among the matters not considered here are (I) the method and place of filing tax 


\section{INTRODUCTION}

The amended tax lien law starts, as the old one did, with an assumption that the general tax lien outranks all competing interests. The 1966 Act made no change in section 6321, which creates a lien in favor of the United States for the amount of tax, together with incidentals, that anyone has "neglected" to pay, upon all his property and rights to property. Chiefly, section 6323 is an elaborate set of qualifications on the assumption that that lien is good against all comers.

A way of summarizing section 6321 and section 6323 would be to say that, as to most persons having commerce with a taxpayer, the filing of a tax lien notice amounts to a general levy on his assets and the attachment of a floating lien to them-with restrictions, however, both as to amount and territory. ${ }^{5}$ The nearest thing to this floating lien is a petition in bankruptcy, which has the effect of a general levy. ${ }^{6}$ The comparison is instructive, and so is the contrast. In bankruptcy there is a tendency, recently accelerated, to put less stress upon the date on which the petition is filed; thus, the trustee must increasingly compromise with interests growing out of the bankrupt's career after the date of bankruptcy. ${ }^{7}$ With at least as much reason, the tax statute concedes that a tax lien filing ${ }^{8}$ does not bring the taxpayer's financial career to a screeching halt, and should not give the government an uncompromising seniority over claimants whose interests depend on later transactions.

The contrast between the government's lien position and its standing in a taxpayer's insolvency proceeding has often been noted, frequently

lien notices, and the requirement of refling; (2) circularity of priorities that will arisein many situations-under $\$ 6323$; and (3) how the amendments may affect the question of marshaling. As to the latter, see Meyer v. United States, 375 U.S. 233 (1963); United States v. Pollack, 370 F.2d 79 (2d Cix. 1966); Kovacs v. United States, 355 F.2d 349 (9th Cir. 1966), cert. denied, 384 U.S. 941 (1966).

5 The form and content of the notice to be filed are prescribed by the Treasury Department. The filing office within a state is commonly one designated by the laws of the state. The choice of state law is determined by the "situation" of the property, as defined in § 6323. See subsection ( $f$ ). Whether filed or not, the lien is a "continuing lien [that] covers property or rights to property in the delinquent's hands at any time prior to expiration." Glass Gity Bank v. United States, 326 U.S. 265, 267 (1945); In re DeAngelis, 373 F.2d 755 (3d Cir. 1967). "A property right of a delinquent taxpayer may be born with a tax lien upon it." Wolverine Insurance Company v. Phillips, 165 F. Supp. 335, 353 (N.D. Iowa, 1958), appeal dismissed, 283 F.2d 518 (8th Cir. 1960).

- MacLachian, BankRuptcy § 183 (1956).

7 See Bankruptcy Act $\S$ 21g, 70d, 11 U.S.C. $\$ \S 44(\mathrm{~g}), 110(\mathrm{~d})$, and especially the construction of the Act in Bank of Marin v. England, 385 U.S. 99 (1966); cf. Segal v. Rochelle, 382 U.S. 375 (1966).

8 "The term 'tax lien filing' means the filing of notice (referred to in subsection (a)) of the lien imposed by section 6321." INr. REv. CoDE of 1954, $\S 6323(\mathrm{~h})(5)$, as added by 80 Stat. 1131 (1966). 
in tones of irony. Under section 3466 of the Revised Statutes, ${ }^{9}$ the United States has won a priority in insolvency proceedings that seems, to some observers, highly ungenerous. ${ }^{10}$ In their view, the Supreme Court's doctrine of inchoate liens has made section 3466 an instrument of oppression. ${ }^{11}$ Professor Gilmore has defended the Court's doctrine by reference to "sovereignty;" 12 and it is unlikely that better scholarly credentials will ever move the controversy over section 3466 past its present level. However that may be, I think it must be acknowledged that the tax lien statutes raise a different set of issues. The effect of a tax lien is not confined to insolvents' estates. It constitutes an intrusion on an order of interests-the system of "property"-that presupposes the recognition of rights adverse to the sovereign. ${ }^{13}$ When Congress modifies the lien to the advantage of competing interests, as it did in 1966, it may well enhance the government's chance of realizing taxes, owing to feeding of the lien by private credits. ${ }^{14}$ It is not, therefore,

0 This statute is said to date back to the early days of the Republic. "With the $\mathbf{1 8 7 5}$ revision of the federal statutes, the priority provision became $\$ 3466$ of the Revised Statutes, and it has, for no known reason, remained the fashion to refer to it under that designation rather than under its current Code number, which is 31 U.S.C. $\$ 191$. Bowing to fashion we shall use the customary Revised Statutes designation." 2 GILMORE, SECURITY INTERests IN Personal Property § 40.2, at 1049 [hereinafter cited as Gilmore]. Chapter 40 of the Gilmore treatise contains a concise and lucid exposition of the course of decisions to date under $\S 3466$, as well as under the tax lien statutes, and contains a selected bibliography.

10 Professor Frank Kennedy has been a steady, learned, and forceful critic of the decisions that have made $\S 3466$ a devouring monster. See Kennedy, From Spokane County to Vermont: The Campaign of the Federal Government against the Inchoate Lien, 50 IowA L. Rev. 724 (1965) (discussing also tax lien cases); Plumb, The New Federal Tax Lien Law, 22 Bus. LAw. 271, 291 (1967).

11 In bankruptcy the $\$ 3466$ priority is very much suppressed, but that does not affect the principle under discussion. See 2 GILMORE § 40.2, at 1051; Plumb \& Wright 165; Kennedy, The Relative Priority of the Federal Government: The Pernicious Career of the Inchoate and General Lien, 63 YALE L.J. 905, 930-32 (1954).

12 "Both the federal Congress and the federal courts have at all times acted with diligence to guard the sovereign prerogative. ... The extent to which the sovereign will yield, and in whose favor, is not a question which is capable of a simple solution. . . . It is just possible that wisdom has been on the side of Congress and the Supreme Court." 2 GILMORE § 40.1, at 1047-48. "As a matter of policy, it is entirely possible to argue that there should be an absolute and overriding priority for all federal claims." Id. § 40.6, at 1073 .

13 See United States v. Vorreiter, 134 Colo. 543, 307 P.2d 475 (1957), rev'd per curiam, 355 U.S. 15 (1957), where Chief Justice Moore, concurring, said that nothing justified the government's claim to priority except: "The good old rule, the simple plan, / That they should take who have the power / And they should keep who can." Id. at 550, 551, 307 P.2d at 479 .

14 See In re Halprin, $280 \mathrm{~F} .2 \mathrm{~d} 407$ (3d Cir. 1960): "[A] federal tax lien tends to defeat its ultimate purpose if it impedes the effective assignment of future earnings as security for funds needed to make such earnings possible. The result of such extension of the 
a simple question of magnanimity that section 6323 raises; at least as much enlightened self-interest may be embodied in the statute. These motives are quite differently mixed, to say the least, in determinations of the government's priority under section 3466 .

The revised tax lien law contains rules that will be of comfort to a host of persons and enterprises who deal with taxpayers in many different capacities: as lawyers, as insurers, as sureties, as lessees, and so on. In every instance it is necessary to examine the precise detail of the statute, for Congress has not painted the tax lien picture with a broad brush. The most intricate parts of section 6323 have to do with contests between secured parties and the government over the taxpayer's assets, and that matter will be the chief province of this paper. The resolution of these contests depends in large measure on the interplay of federal and local law, and I turn first to some definitional problems that will illustrate the potential effect of federal law on concepts customarily defined by state law.

\section{Local LaW and the Tax LIEN}

It is a nice question of tact how far Congress should be expected to go in explicating the federal component of concepts that are partly local in content. It is justified, I believe, in assuming that the courts will be on guard against literalism, and watchful for violations of federal policy. The proper spirit is reflected in Strom v. Peikes, ${ }^{15}$ a bankruptcy case in which a statutory lien was asserted under New York law. The supposed "lien" was found to be nonexistent, even though a local court had attached that name to the claimant's position. In a most revealing passage the bankruptcy court had this to say: "Apart from the question whether or not saying so makes it so, this one statement is of little weight."'16

It is a question of local law "whether and to what extent the taxpayer had 'property' or 'rights to property' to which the tax lien could attach."18 Is there no federal component in this question, however? I believe there is, if we are to be consistent with the approach to other

tax collector's reach is likely to be the destruction of the earning power, and with it the taxpaying power of the burdened business." Id. at 410 .

For conjecture about the course of future decisions under $\S 3466$, see PLumb \&: WRIGHT 160-62, especially n.16.

15123 F.2d 1003, 138 A.L.R. 937 (2d Cir. 1941).

16123 F.2d at 1005 (emphasis added).

17 The term "local law" will refer the courts most frequently to state law, but on occasion it may point to municipal law instead, or to federal law other than the tax lien statutes.

18 Acquilino v. United States, 363 U.S. 509, 512 (1960). 
concepts embodied in the tax lien statutes. In order to make the point I shall have to be somewhat fanciful in expressing a rule of state law. Suppose there were a state statute, regulating the rights of creditors, in the following terms:

At or before the time of obtaining a loan, a debtor may in writing declare himself a trustee for the creditor of a right to payment under a contract requiring performance of the debtor in favor of a third party, together with the proceeds of the contract right. If the declaration also contains a covenant by the debtor that the avails of the loan will be devoted to performance of the contract, the debtor shall have no further interest in the contract right or its proceeds.

Let us now suppose that the taxpayer is an interior decorator who has contracted to decorate a store building. Before the filing of a tax lien notice, he has made the statutory "declaration" in favor of a bank. After it learns of the tax lien filing the bank makes an advance to the taxpayer, and a contest has now developed between the bank and the government over the taxpayer's earnings. The bank's position, of course, is that the taxpayer had no "property" or "rights to property" in the earnings to which the tax lien could attach.

Is the state statute conclusive? Of course it says the taxpayer has "no interest;" but I believe there is still the federal question whether or not saying so makes it so. ${ }^{19}$ One would want to know more about state law than appears on the face of the statute. For instance, if the contractor's earnings are more than sufficient to repay the loan, who is entitled to the surplus? Let us answer this question by saying that the surplus must be devoted to paying persons who supplied the contractor with labor and materials in connection with his work. They are the residual beneficiaries (let us say) of a statutory "trust fund" comprising the earnings. Now I think we must return to section 6323 to see how their interest stands in relation to the tax lien. I should suppose that they may qualify as "mechanic's lienors" for priority over the tax lien; but it is clear that they would not do so if they began to furnish labor and materials after the tax lien filing. ${ }^{20}$ If they are not entitled to priority over the tax lien as "mechanic's lienors" I think it would be staggering to

19 Without necessarily disagreeing with what is said here, Professor Kennedy emphasizes the formalistic aspect of Acquilino v. United States, 363 U.S. 509 (1960), and its companion case, United States v. Durham Lumber Co., 363 U.S. 522 (1960). He rather takes it for granted that labels will continue to have a totemic value: "If the state legislature has not been sufficiently foresighted to qualify the contractor's property interest in the withheld funds, the federal government ordinarily prevails . . . Kennedy, supra note 10 , at 752 .

20 The $\S 6323$ definition makes this point. See $\S 6323(\mathrm{~h})(2)$, set out at note 27 infra. 
conclude either (a) that they prevail against it on some other basis, or (b) that the bank may prevail against it. I therefore think that the state statute is not conclusive. And the sensible explanation is, for me, that the local law label- "no interest"-is an empty one. A federal component in the concept "property" requires that the tax lien attach to the contractor's earnings.

Readers familiar with the "trust fund" provisions of the New York Lien $\mathrm{Law}^{21}$ will have discerned that the problem under discussion is not wholly fanciful. A pro-bank rule similar in effect to our hypothetical statute has been enacted in New York, and I suspect that it is endangered by the federal tax lien. When the trust fund provisions were less extreme than they are now, the Supreme Court gave them a clear right of way over the tax lien, standing firm on the proposition that the federal statute "creates no property rights."22 Nevertheless, as support for the imaginary bank's position, that proposition is a foundation of sheer gossamer.

Just as federal limits must be put on local determination of the taxpayer's interest in "property," similar considerations affect the determination of the interests of a competitor of the government. The use of the word "lien" in section 6323 with reference to non-federal interests makes a nice opening for analysis of the interaction of federal and local law concerning claims against a taxpayer's property.

Prior to 1966 the statute granted protection to a "judgment creditor." This term gave rise to confusion: one judgment creditor claimed priority over the tax lien as to personal property although he had not fixed a lien on it (by attachment, execution or otherwise) until after notice of the tax lien was filed. Naturally the court rejected his literal reading of the statute. ${ }^{23}$ The expression has now been expanded to read "judgment lien creditor." ${ }^{4}$ Of course the statute does not specify how one proceeds to affix a judgment lien, and for this it is necessary to consult state law. ${ }^{25}$ Local law, however, is surely not the final arbiter

21 N.Y. LIEN LAW Art. 3-A.

22 Acquilino v: United States, 363 U.S. 509 (1960), quoted at note 18 supra. See Plumb \& WRIGHT 28-29.

23 Fore v. United States, 339 F.2d 70 (5th Cir. 1964), cert. denied, 381 U.S. 912 (1965). See also United States v. Texas Eastern Transmission Corp., 254 F. Supp. 114 (W.D. La. 1965); Plumb \& WRIGHT 113-17.

24 See $\$ 6323($ a) in text at note 30 infra.

25 A literalist might still make a mistake, if he looked only for state definitions of judgment liens. For instance, in New York the name "lien" is not given to the advantage secured by a creditor who lays an execution in the hands of a sheriff; at least in the Civil Practice Law \& Rules he is said to have a "priority" over other creditors. N.Y. CIv. Proc. Acr § 5234. Yet for the purposes of $\$ 6323, x$ take it, the diligent creditor in New York must be called a "judgment lien creditor"; otherwise he would be senselessly disadvantaged. 
in ascribing lien creditor status under section 6323. This truth emerged vividly in United States $\%$. Gilbert Associates, Inc. ${ }^{26}$ where the Town of Walpole, New Hampshire, claimed "judgment creditor" status for itself, in reliance on local tax collection law. The Supreme Court took the view that this local characterization went beyond the federal perimeters of the concept "judgment creditor." We can be confident that the expanded phrase "judgment lien creditor" is also bounded by a federal perimeter, beyond which local labels are not entitled to credit.

In revising section 6323 Congress gave some attention to the problem of slinging labels when it introduced the priority, mentioned above, for certain "mechanic's lienors." 27 It provided a definition of the term, whereby various imaginable state policies are consciously suppressed if they take the form of enlarging the list of mechanic's liens. The list may not include, for instance, a lien for the improvement of personal property. On the other hand, there is room for deference to local law about what is personal and what is real property. ${ }^{28}$ Again, the government has the advantage of a (hypothetical) bona fide purchaser test, as against an asserted mechanic's lien. Yet section 6323 does not say what it means by "lien." It says that a mechanic's lienor is "any person who under local law has a lien." There is in fact nothing in the definition to preclude a holding that a Uniform Commercial Code security interest in a contractor's earnings is a "mechanic's lien"given certain circumstances. Naturally it would raise a good many eyebrows to encounter such a holding; quite certainly there are limitations on the federal notion of mechanic's lien that are not expressed in the statutory definition.

Even the cursory look we have given to the impact of local law on the tax lien priority reveals that it is no easy thing to discriminate

26345 U.S. 361 (1953). Note, however, the reservations expressed about the continuing vitality of the case in Kennedy, supra note 10 , at 742-43. See also Stevan v. Union Trust Co., 316 F.2d 687 (D.C. Cir. 1963); North Gate Corp. v. North Gate Bowl, Inc., 149 N.W.2d 651 (Wis. 1967).

27 The priority is granted in $\S 6323(\mathrm{~h})(2)$ :

Mechanic's LIENOR.-The term "mechanic's lienor" means any person who under local law has a lien on real property (or on the proceeds of a contract relating to real property) for services, labor, or materials furnished in connection with the construction or improvement of such property. For purposes of the preceding sentence, a person has a lien on the earliest date such lien becomes valid under local law against subsequent purchasers without actual notice, but not before he begins to furnish the services, labor, or materials.

INT. REV. CODE OF 1954, \& 6323(h)(2), as added by 80 Stat. 1130 (1966).

28 'As to what constitutes 'property,' it is intended that what becomes a part of realty is to be determined by local law." H.R. REP. No. 1884, 89th Cong., 2d Sess. 11 n.2 (1966) [hereinafter cited as H.R. REPORT].

S. REP. No. 1708, 3 U.S. Code Cong. \& AD. News 3722, is identical to the House Committee Report in every respect material here. Reference will be made to the House Committee Report only. 
between matters to be ascertained from local law and those federally determined by section $6323 .{ }^{29}$ Although the tax statute often adopts local law as a determinant of priority, there may be places where Congress has inadvertently modified or recast the controlling concepts. The relation between federal law and the Code is of critical importance in connection with the "floating lien," and I turn next to that topic.

\section{Floating Lien v. The Tax Lien}

In construing section 6323 the hardest problems concern contests between the tax lien and private, consensual security interests. As before the amendment, the section asserts the general rule of priority that a security interest in existence before the filing of the tax lien is not subordinate to the government's claim. Subsection (a) expresses this rule, in somewhat altered terms: ${ }^{30}$

The lien imposed by section 6321 shall not be valid as against any purchaser, holder of a security interest, mechanic's lienor, or judgment lien creditor until notice thereof . . . has been filed. ...

For secured parties the major innovations of the new section 6323 involve security interests coming into existence after the filing of the federal tax lien. Subsections (c) and (d) carve out carefully qualified exceptions to the general rule that the government takes ahead of such interests. Recognizing the need for fluidity in certain types of transactions, Congress provided in subsection (c) a 45-day grace period for

29 A distinguished student of tax policy, writing on local law in federal taxation, was once able to brush aside the problem of collection procedure with a "preliminary generalization," as follows: "Diversities of local law . . . can hardly be permitted to interfere with the process of enforcing federal tax assessments." Cahn, Local Law in Federal Taxation, 52 YALE L.J. 799, 804 (1943).

30 The former reference to mortgagees and pledgees has been subsumed under "holder of a security interest." Presumably the former language would have sufficed to protect an entruster in a trust receipt transaction, and a secured party using some other security device. See Stevan v. Union Trust Co., 316 F.2d 687 (D.C. Cir. 1963); United States v. Toys of the World Club, Inc., 288 F.2d 89, 94 A.L.R.2d 739 (2d Cir. 1961); 26 C.F.R. § 301.6323-(I)(a)(2)(ii)(1961); 2 GILMORE § 40.5, at 1067. In any event, now that Article 9 of the Uniform Commercial Code has reduced such distinctions of form, its terminology has appropriately been adopted in the lien statutes. See the Official Comment to UNIForm Commercial CODE § 9-102: "The purpose of this Section is to bring all consensual security interests in personal property and fixtures [with certain exceptions] . . . under this Article ... . The Article does not in terms abolish existing security devices. The conditional sale or bailment-lease for example is not prohibited; but even though it is used, the rules of this Article govern." [Reference herein to "the Code" will signify the Uniform Commercial Code.] 
security interests (those created by "commercial transactions financing agreements") so far as the collateral is inventory, accounts receivable, and the like. ${ }^{31}$ If they come into existence within the grace period, and if certain other requirements are satisfied, security interests of this nature will prevail.

Subsection (c) also grants special dispensation to two other types of financing agreements: "real property construction or improvement financing agreements" and "obligatory disbursement agreements." No fixed time limit is associated with these priorities. If a security agreement fits into one of these categories, and the interest it creates otherwise meets the statutory specifications, priority over the government's claim is granted without regard to the time of filing.

Finally, in subsection (d) the amended act affords a measure of protection to security interests coming into being after the filing of the tax lien by reason of disbursements made after that date. The benefit of this provision is also confined to disbursements within 45 days of the filing; and it accrues only if the collateral was subject to the tax lien at the time the government filed.

As has been indicated, these exceptions to the government's priority are conditioned on the satisfaction of various statutory requirements, some of which are expressed in parallel form in both subsections (c) and (d). No favor is shown in either subsection for loans or disbursements (except "obligatory" ones) made after the financer has "actual notice or knowledge" of the tax lien filing. A post-filing security interest can have priority under one of these subsections only if it had its genesis in a "written agreement entered into before tax lien filing." Similarly, in order to subjugate the government's claim the security interest must be "protected under local law against a judgment lien arising, as of the time of tax lien filing, out of an unsecured obligation."

These requirements represent new federal concepts created by the Tax Lien Act, and they cannot be understood by reference to local law alone. In order to determine the scope of the exceptions embodied in subsections (c) and (d) it is necessary to consider what these new concepts are, or may become as the statute is construed. I shall discuss this matter first, and then explore in some detail problems related to the "floating lien" of the Uniform Commercial Code. In the solution of these problems, it will be seen, a decisive consideration is the relation between local law and the federal law of section 6323 .

31 "In the absence of this grace period, commercial factors and other lenders would have to check on a daily basis to see if a tax lien is filed to protect their interests." H.R. REPORT 2. 
Agreement to Finance

As section 6323 is now written the success or failure of a security interest that competes with the government's claim will depend in many instances upon whether or not, prior to the tax lien filing, there was an agreement to make loans. An agreement to make a financing cash disbursement is a key to priority with respect to the proceeds of a real property improvement contract, just as an agreement to make loans may yield an overriding security interest with respect to "commercial financing security." The observations to be made next apply particularly to commercial transactions financing agreements (as defined in the statute), but the language relating to real property improvement financing agreements is so far similar that a parallel construction is required.

The "agreement" spoken of in the statute suggests an element of compulsion to lend against (or alternatively to purchase) commercial financing security, to judge from the words and structure of the provision granting this priority ${ }^{32}$ It is not the sort of compulsion described in the definition of "obligatory disbursement agreement," which speaks of disbursements "required to be made by reason of the intervention of the rights of a person other than the taxpayer." 33 On the contrary, the priority in commercial financing security may be founded on the taxpayer's right to a loan, and it is far from clear that the requisite agreement must amount to anything like a formal loan commitment. Notoriously there are "soft loans," and it is apparent that loan commitments range sharply down from the firm to the squashy. Professor Gilmore argues, indeed, that a loan commitment is a nonesuch, conceptually speaking. "The contract to lend money is thus a most peculiar animal: maybe it is not a contract at all; if it is, it is a contract which may be breached with impunity." ${ }^{34}$ As he reads the cases, the supposed distinction between obligatory and voluntary advances allows for a liberal exercise of judicial discretion, permitting courts to classify loans " $a d$ hoc or ad hominem,"35 and to order priorities accordingly. One sure thing about section 6323 is that it does not restrict the area for discretionary decisions.

32 If this is so, the statutory protection does not extend to the voluntary "future advances" that seem to have been made in Hammes v. Tucson Newspapers, Inc., 324 F.2d 101 (9th Cir. 1963). Although the court took pains to conceal what it was doing, it evidently went far beyond the new $\S 6323$ in subordinating the tax lien.

The agreement, it is said, "need not embrace an unconditional obligation to make the loans." Plumb \& Wright 81 n.48.

33 See text accompanying notes $38-42$ infra.

342 GLMORE § 35.4, at 926 .

35 Id. at 929-30. 
If elements of equity are to be weighed into such decisions, it is a circumstance worthy of reflection that the funds advanced by the private party to the taxpayer and the property purchased with such funds come under the government's lien. If the lien outranks the lender's interest in the collateral, the lender is made an unwitting contributor to the government's coffers, and can be pictured as a victim of its greed. Yet the precise object of section 6323 is to inter that apparition. The critical language appears in the definition of "commercial transactions financing agreement," and (as abstracted) it runs:

an agreement to make loans to the taxpayer to be secured ... but such an agreement shall be treated as coming within the term only to the extent that such loan is made . . . .

The conceptual argument of Professor Gilmore (as opposed to his concession to psychological factors) ${ }^{37}$ leads to the following paraphrase: "an agreement contemplating loans to be secured ....," omitting any notion of compulsion. Alternatively, the courts may hew to the line of contract duty and determine as to each advance, outfacing the difficulties, whether or not a refusal to lend would have signified a breach. Still a third course is arguably open: to inquire whether or not the advance in question can be justified by responsible commercial practice. The very subtlety of that inquiry is an objection to making the attempt.

\section{Obligatory Disbursement Agreements}

Unlike the statute's ambiguous use of "agreement" in relation to "commercial transaction financing," its treatment of "obligatory disbursement agreements" leaves a court relatively little room for the exercise of discretion. A loan commitment is not within the protection given to an obligatory disbursement except "to the extent of disbursements which are required to be made by reason of the intervention of the rights of a person other than the taxpayer." Furthermore, the favored security interest may extend to property acquired by the taxpayer after filing only "to the extent that the acquisition is directly traceable to the [required] disbursements." 38

How useful is the exception for "obligatory disbursement agreements" likely to be? That will depend, of course, very much on

36 INT. REv. Code of 1954, $\S 6323$ (c)(2)(A), as added by 80 Stat. 1127 (1966).

37 See 2 Gilmore \& 35.4, at 926 n.4.

38 INT. REv. CoDE of 1954, $₹ 6323$ (c)(4)(B), as added by 80 Stat. 1128 (1966):

Limitation on QUALIFIED ProperTY.-The term "qualified property," when used with respect to an obligatory disbursement agreement, means property subject to the lien imposed by section 6321 at the time of tax lien filing and (to the extent that the acquisition is directly traceable to the disbursements referred to in subparagraph (A)) property acquired by the taxpayer after tax lien filing. 
the character of the collateral. It will plainly be a considerable comfort to a bank financing a taxpayer in the purchase of goods under a letter of credit. ${ }^{39}$ But what of a person doing financing on a contractor's earnings? Inevitably there will be a mingling of contributions when the builder's progress payment accrues: the monthly payroll may have been met out of cash advances; materials installed on the job during the month may have been supplied on credit; and the builder's own energy and skill will have been devoted to moving the work forward-not to mention his acumen in getting the contract in the first instance. Need the financing bank or supplier be more "direct" in their tracing than this? If so, it is possible that credit given torvard real property improvement must seek favor without aid from the concept of "obligatory disbursement." The fact that real property construction and improvement financing is separately dealt $w^{2} \mathrm{th}^{40}$ reinforces this suggestion as to the meaning of "traceable." 41 Financing banks and suppliers should be wary, then, about any agreement with the builder's employer to "see him through."

The sharp distinction between an existing security interest and a potential one is vividly displayed by the provisions about obligatory disbursements. Take, for instance, a security agreement covering the equipment of a machinist. We may readily imagine that he lands an order to produce a quantity of goods only by giving assurances that he will be adequately financed for the job, and that his bank binds itself to grant him a certain line of credit by agreement with his customer. At this juncture, let us suppose, notice of a tax lien is filed against the machinist. Subsequently he buys and installs a machine tool, which thereupon becomes subject to the bank's security agreement. When the bill for the tool is presented a month later, the bank supplies funds to pay it. This "parting with money" evidently qualifies as an obligatory disbursement, and the security interest resulting from it is protected against the tax lien if the tool is "qualified property," and that is the case if "the acquisition is directly traceable to the [required] disburse-

39 "An example [of an obligatory disbursement agreement] is an irrevocable letter of credit where a bank issuing the letter must honor a demand for payment by a third party who advances credit in reliance upon the letter." H.R. REPORT 9.

40 INT. REv. CODE of 1954, § 6323(c)(1)(A)(ii), (3), as added by 80 Stat. 1127 (1966).

41 Does $\S 6323$ - "directly traceable"-imply a federal rule for tracing an obligatory disbursement to an acquisition? Or does state law supply the tracing rule that limits the priority? A somewhat comparable issue arises in bankruptcy, where it has been thought that certain state rules might be incompatible with the federal scheme. The question, it is said, "has not been authoritatively settled." Sonnenschein v. Reliance Insurance Company, 353 F.2d 935, 937 n.2 (2d Cir. 1965). In In re Rhine, 24I F. Supp. 86 (D. Colo. 1965), it was assumed that state rules control. In tax lien cases the federal policy is likely to be more prominent than in bankruptcy. 
ments." 42 Possibly one reading of this language would be that the disbursement must be contemporaneous with the acquisition-but that would be a malignant reading. Whereas we may hope that the bank would prevail, it would evidently not prevail against the tax lien without tracing its funds to the seller of the tool.

Contrast the easy victory for the bank if the sequence of events is slightly changed: suppose the tax lien notice had been filed later, immediately after the taxpayer acquired his new tool. In this case the tool qualifies as "property subject to the lien ... at the time of tax lien filing." Hence the lien is invalid as to the bank's interest in the tool. One wonders why the bank's protection should depend upon tracing of its funds to the acquisition in the former case, if not in this one. By hypothesis the bank cannot help parting with its money, and be true to its contract with the taxpayer's customer. Having made that contract, and the security agreement, prior to the filing, it might sensibly have been protected as the "holder of a security interest" prior to the filing; that would be the path of true magnanimity. Instead, section 6323 recognizes at most that the bank's arrangements gave it a potential of having a security interest.

\section{"Protected" Under Local Law}

In addition to requiring an "agreement" in order for a post-filing security interest to prevail over the tax lien, subsections (c) and (d) provide that the interest must be "protected under local law against a judgment lien arising, as of the time of tax lien filing, out of an unsecured obligation." What does the word protected mean here? Until one settles on the proper construction of this word, he cannot reach firm conclusions about many of the questions raised by the statute.

In the first case reported under section 6323 as newly amended, United States $v$. Strollo, ${ }^{43}$ the court took a constricted view of the word "protected." The taxpayer (Van Cleave) was in business as an interior decorator, and on December 17, 1963, he entered into a contract with the owners of Strollo's restaurant. Previously (as early as July 5) the Peninsula State Bank had filed with the Florida Secretary of State notices of assignments by Van Cleave of accounts receivable, under the Florida notice-filing statute. Also, on November 29, the government had made a tax lien filing against Van Cleave. On December 23, Van

\footnotetext{
42 INr. Rev. Cone of 1954, § 6323(c)(4)(B), as added by 80 Stat. 1128 (1966), set out in note 38 supra.

43 CCH 1967 Stand. Fed. Tax Rep. (67-1 U.S. Tax Cas.), If 9142 at 83,162 (Fla. App. Dec. 21, 1966). The transactions occurred long before 1966, but the government "conceded" that the amendments of that year applied to the case.
} 
Cleave borrowed more than $\$ 1,500$ from the bank, and gave it a promissory note and an assignment of the Strollo contract as security. Upon completion of the job by Van Cleave, the Strollos deposited about $\$ 1,000$ into court as proceeds of the contract, to which conflicting claims were made by the bank and the government.

The argument made for the bank rested on the statutory priority for commercial transactions financing agreements, in subsection (c). The decision went against the bank, however, on the ground that its security interest was not one "which [was] protected ... as of the time of tax lien filing." The court observed that the Strollo contract was not entered into until after that. "It was not in existence as a "valid and then subsisting contract' until that date, and thus the Bank's assignment of that contract could not be 'protected' prior to that date." 44 The opinion seems to say that a security interest in after-acquired property is not "protected" in the federal sense until the interest arises.

One would like to argue that Strollo was wrongly decided by invoking against it the canon that no part of a statute is to be construed as a redundancy. One would like to say that subsection (c) of section 6323 is an elaborate nothing if it only applies when the secured party has (in the court's sense) a protected security interest before the tax lien filing-for then he has priority under subsection (a). For me, however, this argument is not available. Granted that the bank lacked priority under either subsection, it will be seen that subsection (c) may at least afford priority to a secured party in other circumstances - as for instance an inventory financer claiming returned goods. It does so if the goods are "proceeds" of a protected security interest-one that was in existence at the time of filing.

It must be accounted a piece of bad luck that the Strollo case arose in Florida. When it is remembered that the Florida notice-filing statute for accounts receivable used the word "protected" to signify what the Code means by the word "perfected," 45 the court's reasoning is easier to condone. In the tax lien statute "protected" does not mean "perfected." The draftsman of the federal statute had a problem of diction on his hands in writing clause (B) of subsection (c)(1); the problem is easy to see if we imagine that he had said "perfected" at the time of tax lien filing. Of course, the Uniform Commercial Code does not allow

44 Id. at 83,164 .

45 Fla. STAT. ch. 524 (1961). Section 524.04 read, in part:

(1) A written assignment . . becomes protected at the time the assignee:

(a) Files a notice of assignment after taking an assignment or

(b) Takes an assignment during the effective period of the notice.

(2) A protected assignee takes subject to:

(a) Judicial liens on the account at the time his assignment became protected; .... 
for perfection of a security interest before it attaches. ${ }^{46}$ In choosing his words as he did, the draftsman evidently sought to deal with noticefiling under the Code in advance of the attachment of a security interest. Awkward it may be, but the language appears designed to impose a requirement that the (now) secured party have exercised a degree of diligence by making an early notice-filing, in order to oust the tax lien.

The word "protected" appears in subsection (d) of section 6323 as well as in subsection (c). In writing subsection (d), the draftsman seems rather clearly to have had in mind security interests that have not attached at the time of tax lien filing, not even to some antecedent item of collateral, now changed in character. He spoke there of disbursements by the secured party, after the tax lien filing, which call the interest into existence. Again in this provision the priority hinges on the fact that the interest "is protected . . . at the time of the tax lien filing." To test subsection (d), the facts of the Strollo case may be varied to pose a situation in which the bank provided "future advances." Let us assume that a tax lien filing did not occur until the taxpayer had given a security agreement covering contract rights, and the proceeds thereof, and had made a contract for interior decorating within the agreement. Following the tax lien filing the bank makes an advance to the taxpayer, not having made an earlier one. On these facts it is submitted that the bank may have priority over the tax lien. To establish the priority the further facts must be assumed that (1) the bank made its advance within forty-five days of the tax lien filing, and (2) it did not have "actual notice or knowledge" 47 of the filing at the time of the advance.

There is the pesky further requirement that the interest be "protected . . . as of the time of the tax lien filing." 48 It would seem that

46 "A security interest is perfected when it has attached and when all of the applicable steps required for perfection have been taken. . . . If such steps are taken before the security interest attaches, it is perfected at the time when it attaches." UNIForm CoMMIERCIAL CODE § 9-303(1). As to the Code term "perfection" in general, see I GiLMore 435-37.

47 "Actual notice or knowledge" is the subject of a "special rule" in $\$ 6323(\mathrm{i})(\mathrm{l})$.

48 Section 6323(d) reads as follows:

45-Day Period for Maring Disbursenients.-Even though notice of a lien imposed by section 6321 has been filed, such lien shall not be valid with respect to a security interest which came into existence after tax lien filing by reason of disbursements made before the 46th day after the date of tax lien filing, or (if earlier) before the person making such disbursements had actual notice or knowledge of tax lien filing, but only if such security interest-

(1) is in property (A) subject, at the time of tax lien filing, to the lien imposed by section 6321 , and (B) covered by the terms of a written agreement entered into before tax lien filing, and

(2) is protected under local law against a judgment lien arising, as of the time of tax lien filing, out of an unsecured obligation.

INr. REv. CoDE of 1954, § 6323(d), as added by 80 Stat. $1128-29$ (1966). 
this requirement is met if the bank has filed a financing statement ${ }^{49}$ prior to the tax lien filing: that makes the clause intelligible, subjecting the bank to a comparative-diligence rule. Unfortunately, it is not the only intelligible reading of the clause. Arguably the statute means that the government has hypothetical judgment-lien-creditor status vis-a-vis the security interest. Depending upon local collection law, ${ }^{50}$ the bankassignee may or may not be "protected" against such a creditor. If an unearned right to payment for work may be subjected to a "judgment lien," the bank will not gain priority over it by extending credit thereafter-for the first time-as a voluntary act, even though his filing was earlier. If that kind of priority is intended by the word "protected" in subsection (d), then the tax lien would outrank the bank's assignment. ${ }^{51}$

Further complexities arise if we change the facts by supposing that the bank gave credit before the tax lien filing, as well as after. In such a case, there may be only a single security interest, and the after-filing disbursement may be regarded as swelling the size of that interest rather than creating a new one. Professor Gilmore has argued that this is the effect of future advances under the Code. ${ }^{52}$ On that assumption section 6323(d) is irrelevant to the bank's position; it would find a sure footing for priority under subsection (a), as the "holder of a security interest" prior to the tax lien filing.

Under the Code, it is clear that a creditor acquires a security interest -other things being auspicious-at the time he gives "value," and that he gives value to the extent that he has extended immediately available credit, or has made a binding commitment to extend credit.53 By contrast, section 6323 does not recognize the existence of a security interest

49 Under the Code, filing a financing statement (see UNIFORM CoMmerciaz Code \$\$ 9-401-02) is the only possible mode of perfecting an assignment of accounts or contract rights (not "proceeds") that is embraced by Article 9, except for the assignments mentioned in UnIForm CoMmercial CODE \$ 9-302.

50 See Comment, Garmishment of Intangibles: Contingent Obligations and the Interstate Corporation, 67 CoLum. L. REv. 550, 553-58 (1967).

51 The assumption underlying this discussion is that the contract right constitutes "property" or a "right to property" of the taxpayer, within the meaning of $\S 6321$. See, however, the text accompanying note 69 infra.

52 "It is not entirely clear whether successive loans against the same collateral create separate security interests, as in the case of after-acquired property, or only one which attaches and becomes perfected with the first loan and thereafter varies as to amount. ... $[T]$ he Code lends itself to the construction that only the secured party who has made a 'binding commitment' will take priority as to his future advances over intervening liens. ... . [But] the alternative construction which protects the future advance secured party over intervening liens without regard to the nature of his commitment is equally possible. With some trepidation the present writer is inclined to ally himself with the second group." 2 GILMORE § 35.6, at 937-39.

53 UNIFORM COMMERCIAL CODE §§ 1-201(44), 9-204(1). 
to that extent. It seems that the draftsman of the tax statute sought to forestall the possibility just mentioned with its special definition of "security interest": 54 "A security interest exists at any time . . . to the extent that, at such time, the holder has parted with money or money's worth." This definition is evidently designed to exclude security interests so far as they depend upon the Code's "binding commitment"-not to mention more ephemeral categories of value such as "consideration sufficient to support a simple contract." Working on this assumption, we must conclude that giving a commitment for credit to be extended in the future is subject to a tax lien hazard. ${ }^{55}$ There is a moral in this, to be learned before drawing up a security agreement covering obligatory future advances: in stating the events constituting default, an essential one is the filing of a tax lien notice against the debtor.

\section{Inception of Security Interest}

In the foregoing discussion we have seen that security interests claiming the favor of section 6323 may encounter difficulty with the statutory elements "protection" and "agreement." In what follows we shall inquire into the Code concept of "attachment" of a security interest, and how it relates to the inception of a security interest recognized in the Tax Lien Act. Are these notions identical, so far as concerns a security agreement covering after-acquired property? Or is there a federal concept of "attachment," at variance with local law, which affects contests for priority between secured parties and the government? The question is one peculiarly pertinent to floating liens.

One of the notable features of the Uniform Commercial Code is the liberty it allows in the granting and taking of security interests. The "new fangled" uses of personal property are nicely suggested in a lament by a bankruptcy referee:

The old-fashioned method of operating a business on the strength of equity capital and unsecured bank credit based upon the financial integrity of the debtor seems to be giving way to the modern trend of financing business operations in reliance upon a floating lien on current assets with little or no regard for equity capital. ${ }^{56}$

54 See text accompanying note 60 infra.

55 Presumably this is so even though the financing party is already the "holder of a security interest" at the time the notice of lien is filed, having parted with some money or money's worth. Although $\S 6323$ (a) says the unfiled lien is not valid as against him, it must mean that the interest created by the credit drawn upon is protected.

56 In re Portland Newspaper Publishing Co., 3 UCC REP. SERv. 194, 214 (D. Ore. 1966) (referee's opinion). 
Obviously a modern revision of the tax lien statutes raises this question of policy: Should indulgence be shown for the "floating lien on current assets?"

One of the keys to the Code's treatment of the floating lien is section 9-204(3), which provides, with a smallish exception, that "a security agreement may provide that collateral, whenever acquired, shall secure all obligations covered by the security agreement"; that is to say, after acquired property clauses are generally effective. A second key to the Code validation of floating liens is found in section 9-306(2) on "proceeds" of collateral, which allows for the shift of a security interest, without loss of status, to new items of collateral. Finally an inventory financer's security is significantly protected by the Code's section $9-306(5)$, which provides that he may maintain his hold on goods that have been sold and repossessed by the merchant debtor, bridging the period when the debtor held an account against his customer for the unpaid purchase price. The transferee of the account, such as a factor, also has a security interest in the returned goods; but it is made subordinate to that of the inventory financer.

Needless to say, these provisions do not serve to safeguard a secured party, whether inventory financer or factor, against a United States tax lien that arises against the debtor before the goods are returned or repossessed. Moreover, it is not at all clear that the United States should abide by a state-law determination in favor of floating liens. The shifting and spreading and floating of an inventory financer's security interest is not, even in the universe of the Code, an unlimited advantage, for the priority of his interest will give way to the rights of various sorts of "purchasers," including some purchasers who do not give new value. Similarly, the federal statute provides that the floating lien for the tax claim gives way to the rights of various transferees. In considering whether the Code's floating lien should be senior or junior to the tax lien, Congress could intelligibly have taken the view that the tax lien must not be ousted by the shifting and floating qualities of the inventory security interest if, taking all things together, precedence over the state-created interest of the inventory financer is perceptibly easier to obtain than precedence over the tax lien. I have in mind particularly the fact that, under the Code, a security interest in inventory may readily be subordinated to a purchase-money interest in the same collateral. ${ }^{57}$ In view of this, the inventory financer's interest is something of a "residual" one; and there is no reason ex necessitate for the tax lien to stand behind it. At least, before saying that it should,

57 UNIFORM COMMERCIAL CODE § 9-312(3). 
one would like to know how the tax lien itself ranks in relation to a purchase-money security interest. This, as we shall see, is largely an open question.

A Code floating lien will outrank the tax lien, under subsection (a) and (c) of section 6323, it appears, only if it "existed" at the time of tax lien filing or within 45 days thereafter. The existence of a security interest has to be considered in relation to the Code concept of attachment to the collateral. Using an inventory financer as an example, the following discussion will illustrate the difficulties that arise in determining when a security interest comes into existence.

Let us hypothesize the following case:

(1) a financer takes and perfects a security interest in inventory

(2) there is a tax lien filing

(3) the debtor-taxpayer sells collateral out of inventory on open account

(4) goods sold are returned by the customer for credit, augmenting inventory and terminating the account.

It is a nine day's wonder that we do not know in this situation when an inventory security interest attaches to the returned goods under local law. The Code says that it "attaches again" when the goods are returned, ${ }^{68}$ meaning apparently that it has attached previously and been divested by the sale. For the secured party that is an unfortunate view to take, in the event of an intervening tax lien. Yet it is probably necessary to take that view if the security interest embraces nothing but goods. Ordinarily that will not be the case, for accounts arising from the sale of collateral are (or may be) the subject of a continuing security interest, as "proceeds." In the eye of the Code lawyer, then, the financer's interest may be continuous, in property that alternates in form: goods, account, goods. Perhaps the Code envisages only a single "attachment" of the interest. If so, the financer may search for a tax lien filing against the merchant, and finding none he may make sure that his current advance against goods then in stock is secure, to that extent, against the tax lien.

In the federal eye, however, a security interest does not necessarily come into existence when state law recognizes it. In relation to returned goods, and a security agreement embracing both goods and accounts, it is possible to say that the security interest lives three successive and distinct lives, attaching and re-attaching as goods are (1) brought under the agreement, (2) sold, and (3) returned. There is some indication in 
the tax lien statutes that various forms of collateral-inventory, contract rights, accounts receivable, and so on-are to be regarded as separate properties, ${ }^{59}$ notwithstanding the fact that they are connected one with the other by the processes of exchange and collection. If they are so regarded, the floating lien is (in Professor Gilmore's phrase) a sitting duck for the federal tax lien.

Section 6323 contains no explicit answer to the question whether local law or federal law determines the continuity of a security interest in successive forms of collateral. If a federal rule on the subject is to be extrapolated from the statute, the starting point is doubtless subsection (h), where the term "security interest" is defined:

The term "security interest" means any interest in property acquired by contract for the purpose of securing payment or performance of an obligation or indemnifying against loss or liability. A security interest exists at any time (A) if, at such time, the property is in existence and the interest has become protected under local law against a subsequent judgment lien arising out of an unsecured obligation, and (B) to the extent that, at such time, the holder has parted with money or money's worth. ${ }^{60}$

The expression "interest in property," as it appears in this definition, is open to diverse interpretations. The statute does not define it directly; neither does it direct us explicitly to local law for the identification of an "interest in property." There is a distinct possibility, at least, that the expression implies a federal limitation, and that federal tax law does not defer entirely to local law for the determination whether or not the return of goods, and similar processes, integrates new and old forms of collateral under a security agreement.

Even if the Supreme Court continues to insist that local standards determine what property interests the taxpayer holds, federal standards are sure to play a part in evaluating rights that are claimed adversely to both him and the government. Section 6323 demands this. In making reference to certain rights of this character (rights under contracts of lease or purchase), it directs that they "be treated as" interests in property. This provision is part of the definition of "purchase," and it evidently forestalls the government's reliance on the narrowest notion of "purchase" that might be found in local law. As concerns purchasers and secured parties (among others), it may well be that the content of the expression "interest in property" will be determined largely by federal law-or federal improvisation. If not, one may well imagine

59 See text accompanying note 82 infra. Also, "proceeds of the contract" that is financed [subsection (c)(3)(B)(ii)] or ensured [subsection (c)(4)(C)] are singled out.

60 INT. REV. CODE OF 1954, § 6323(h)(1), as added by 80 Stat. 1130 (1966). 
how the tax lien might be eviscerated by huge cloudy notions of local law about the constituents of "purchase" and "security interest."

Returning to our inventory financer, claiming an interest in returned goods, we are unable to say with conviction when the interest had its inception. The Code speaks ambiguously to the question, and our doubt is intensified by reference to section 6323 , where an inference may be found that federal law controls the continuity of the interest in successive forms of collateral. If the financer is regarded, by either local or federal law, as having held three security interests in turn, then he must look for comfort to the priority for "commercial transactions financing," as defined in subsection (c) ${ }^{61} \mathrm{He}$ will find it there only if the goods were returned within forty five days of the tax lien filing. ${ }^{62}$ Furthermore, in order to claim the benefit of this subsection he must overcome the difficulties of construction discussed above: he must establish both that he had entered into the necessary "agreement" and that his interest was "protected" under local law at the time of tax lien filing.

\section{A Specimen Case: In re Halprin}

Having explored some of the doubts that section 6323 raises about floating liens, we are in a position to test its application to an assignment of intangibles. A 1960 case, In re Halprin, ${ }^{63}$ describes a suitable situation for study. Halprin had been engaged by a garment manufacturer, Doniger, to sew material supplied by Doniger into jackets. Several months later Halprin borrowed from a finance company in order to meet his payroll, and gave it an assignment of "all sums to become due in the future under the then executory Doniger contract." As a result of Halprin's work under the contract, Doniger became indebted for some $\$ 3,000$. The United States had filed a tax lien notice

61 INT. Rev. CODE of 1954, § 6323(c), as added by 80 Stat. 1127 (1966):

(2) Commiercial Transactions Financing Agreement,-For purposes of this subsection-

(A) Definition.-The term "commercial transactions financing agreement" means an agreement (entered into by a person in the course of his trade or business)-

(i) to make loans to the taxpayer to be secured by commercial financing security acquired by the taxpayer in the ordinary course of his trade or business, or

(ii) to purchase commercial financing security (other than inventory) acquired by the taxpayer in the ordinary course of his trade or business; but such an agreement shall be treated as coming within the term only to the extent that such loan or purchase is made before the 46th day after the date of tax lien filing or (if earlier) before the lender or purchaser had actual notice or knowledge of such tax lien filing.

62 If they were returned later, the financer would have to argue that the taxpayer had an existing interest in the "prospective inventory" within the grace period. The concept is suggested in note 82 infra; but one would not put much confidence in it.

63280 F.2d 407 (3d Cir. 1960). 
against Halprin after the contract was made but before the debt arose, and it made a claim (in Halprin's bankruptcy) on the account receivable. Of course, the finance company contested the government's claim.

Let us first suppose that the assignment was made before the tax lien filing, and that Halprin did the work giving rise to the account more than forty five days after filing. On that assumption the finance company has slight chance of gaining priority over the government. The finance company might have obtained a security interest when it made the loan if it had taken an assignment of Halprin's existing rights in the Doniger contract, rather than relying (as the opinion suggests it did) on an assignment of collateral to be acquired in the future, the "account." 64 As to the account, the difficulty is that the security interest did not come into existence under either the Code or the federal statute until Halprin's right to payment was earned by performance. When this item of property came into existence, we may surmise, the security interest and the tax lien attached simultaneously. If that is so, do they rank equally? More probably one of them has priority over the other; but which one? We simply do not know the answers to these questions. ${ }^{65}$ It seems unlikely that section 6323 (a) awards the palm to the assignee; but the situation may be casus omissus in the statute. ${ }^{66}$

Although under local law the assignee's interest first attached when the account arose, ${ }^{67}$ it would be perfectly possible to say that the tax lien had its inception earlier, because the lien attaches to "all property and rights to property . . . belonging to" the taxpayer. ${ }^{68}$ Yet the court that decided Halprin's case reasoned that "Doniger's promise to pay

64 The Code defines "account" and "contract right" in \$ 9-106: "Account' means any right to payment for goods sold or leased or for services rendered which is not evidenced by an instrument or chattel paper. 'Contract right' means any right to payment under a contract not yet earned by performance and not evidenced by an instrument or chattel paper."

Under a set of statutes that flourished during the late 1940's and 50's, concerning accounts receivable financing, there was a round of litigation over the statutory term "accounts." 1 GILMORE $\$ 8.7$, at 279. The issue is again before the house because of the appearance of the term "accounts receivable" in \$ 6323; see text accompanying note 82 infra.

65 The answer might have been found in In re Halprin, 280 F.2d 407 (3d Cir. 1960), except that the court relied on other circumstances.

A subsidiary question would be whether or not a pre-lien filing by the government can give it an advantage. A recent decision holds that it may. North Gate Corp. v. North Gate Bowl, Inc., 149 N.W.2d 651 (Wis. 1967). But see United States v. City of New Britain, 347 U.S. 81, 85 (1954) ("first in time is the first in right.").

66 See Creedon, The Federal Tax Lien Act of 1966, 4 Harv. J. Legs. 163, 175 (1967). 67 "A security interest cannot attach until there is agreement that it attach and value is given and the debtor has rights in the collateral." UNIForm ComMERcial Code § 9-204(1). 68 INT. REv. CODE OF 1954, § 6321 . 
for goods if and when delivered, as stated in an executory contract did not constitute 'property ... belonging to' Halprin, subject to a tax lien under section 6321."69 This was a dubious position. The Supreme Court has always insisted that the courts "must look to state law" to find out whether or not a taxpayer has property to which a lien can attach. ${ }^{70}$ The Halprin court reached its position by construing the federal phrase, and not by way of state law. ${ }^{71}$ The court's reasoning would be even more suspect now that section 6323 has been amended. In introducing its definition of a "security interest," Congress used the term in a way powerfully implying that the tax lien act embraces contract rights. One object of the amendment was to accommodate Code concepts in the tax lien scheme, ${ }^{72}$ and of course many sections of the Code concern the interests of secured parties-and debtors-in contract rights. Although the federal phrase in section 6321 has not been changed, the new section 6323 will not yield sense if a taxpayer's contract rights cannot be "property."

Yet the reasoning in Halprin will finally be vindicated, in part, if the Supreme Court accedes to the view that the application of section 6321 "involves a two-step inquiry in which both state and federal law must be consulted."73 The new federal definition of "security interest" will have a repercussion, I predict, on the Court's doctrine of deference to state law; in the future, both state and federal law will probably have to be consulted in the application of sections 6321 and 6323. For example, there will be the question whether or not a consignment of goods to a taxpayer creates a security interest; and it will be found that

69 In re Halprin, 280 F.2d 407, 410-11 (3d Cir. 1960). But see Seaboard Surety Co. v. United States, 306 F.2d 855 (9th Cir. 1962).

70 "The threshold question in this case, as in all cases where the Federal Government asserts its tax lien, is whether and to what extent the taxpayer had 'property' or 'rights to property' to which the tax lien could attach. In answering that question, both federal and state courts must look to state law, for it has long been the rule that in the application of a federal revenue act, state law controls in determining the nature of the legal interest which the taxpayer had in the property ... sought to be reached by the statute.' Morgan v. Commissioner, 309 U.S. 78, 82. Thus ... Section 3670 [the predecessor of Section 6321] creates no property rights but merely attaches consequences, federally defined, to rights created under state law . . . United States v. Bess, 357 U.S. 51, 55." Acquilino v. United States, 363 U.S. 512-13 (1960).

71 See Note, Property Subject to the Federal Tax Lien, 77 HARv. L. REv. 1485, 1495-96 (1964). Another strand in the court's reasoning, having to do with third-party beneficiary contract theory, has caused some confusion. See Havighurst, Relative Priority of Federal Tax Liens and Assignments of Rents in Lease Financings, 19 Bus. LAw. 939, 945-57 (1964).

72 "This bill is in part an attempt to conform the lien provisions of the internal revenue laws to the concepts developed in this Uniform Commercial Code." H.R. REPORT 1-2.

73 In re Halprin, 280 F.2d 407, 409 (3d Cir. 1960). 
state law-the Code-characterizes some consignments as security interests, but not others. ${ }^{74}$ If, as appears likely, the federal and local concepts turn out to be congruent, at this point, ${ }^{75}$ it may be explained on the ground that local law supplies some of the components of the federal definition; or alternatively, we may find that the federal definition operates to create property rights in the taxpayer.

State law on the question "What is property?" is subject to an intense controversy which goes to the present actuality of future prospects. Consider a garment maker who assigns a mass of accounts receivable, continuously arising, that grow out of his business with many customers. One position to take, persuasively supported by Professor Gilmore, is that "the future earnings or receivables of an enterprise can, and on the whole should be, considered as a presently existing aggregate or entity." 76 The contrary view held in some quarters is that Article 9 requires each contract right and each account to be regarded as having a separate inception. ${ }^{77}$ Glearly these views might have very different consequences as concerns priority between the assignment and a tax lien, since the time when a security interest comes into "existence" determines when the tax lien outranks the private claim. I shall not enter the arena of this controversy. It is now being thrashed out in the

74 "Unless a lease or consignment is intended as security, reservation of title thereunder is not a 'security interest' . . . ." UNIFORM CoMmercial CODE § 1-201(37).

75 The possibilities seem to be these: (1) Some Code security consignments will prove not to create $\$ 6323$ security interests, and will effectively hold title against the tax lien. The difficulty with this is that the label "consignment" could be used to frustrate tax collection. Cf. Fowler v. Pennsylvania Tire Company, 326 F.2d 526 (5th Cir. 1964). (2) Even consignments that are "genuine" ones under the Code create $\$ 6323$ security interests. But it would be difficult to read $\S 6323$ this way. (3) The Gode and $\S 6323$ are congruent at this point. As argued in the text, it would be hard to believe that this is so unless the 1966 amendments have refined the notion of the consignee-taxpayer's property; can he have "no property" in the goods if the consignor has a security interest in them?

There is some reason to believe, as will be seen, that Congress meant purchase-money security interests to have a priority over the tax lien without saying so in the statute. If that is so, there was no occasion to design a definition of "security interest" embracing consignments. Contra, Creedon, The Federal Tax Lien Act of 1966, 4 HARv. J. LEGrs. 163, 168 (1967) ("The conditional vendor [is] obviously included."). This reflection tends to support the first possibility mentioned above. But possibly the most satisfactory reading, in policy terms, would be the second. It would mean that virtually every consignor would have to file a Code financing statement to reach safe haven, with respect to the tax lien, just as he must with respect to ordinary creditors of the consignee. The interaction of the Code and the tax lien statutes as they may affect consignments is no simple matter.

762 GILMORE § 45.5, at 1307.

77 See Gordon, The Security Interest in Inventory Under Article 9 of the Uniform Commercial Code and the Preference Problem, 62 Colum. L. REv. 49 (1962), revised as Chapter 11 of 1 Coogan, Hogan \& Vagts, Secured Transactions (1963). 
context of section 60 of the Bankruptcy Act, ${ }^{78}$ rather than in tax lien cases. However, if $\mathrm{I}$ am right in suggesting that in the future federal components will figure in the phrase "property and rights to property," they militate strongly against the conception of "future earnings or receivables" as an existing entity, because such a view would create unintended inroads on the scope of the tax lien.

Going back to the Halprin case, let us suppose that the assigned account arose-was earned-within forty five days after the tax lien filing. ${ }^{79}$ In this case section 6323 (c) offers assurance, or the means of assurance, to the financer. If he sets up the transaction in a business-like way, his assignment appears to fit easily into the statutory description of a "commercial transactions financing agreement." 80 One requirement is that the agreement have reference to "commercial financing security," as defined. ${ }^{81}$ This term embraces accounts receivable, inventory, real property mortgages, and chattel paper. I have argued that it does not embrace prospective accounts. 82 The security must be "ac-

78 See Rosenberg v. Rudnick, CCH INST. CREDIT Guide I 98,135 (D. Mass. 1967); In re Portland Newspaper Publishing Co., Inc., 3 UCG ReP. SERv. 194 (D. Ore. 1966) (referee's opinion).

79 A leading proponent of the 1966 amendments, Mr. William T. Plumb, Jr., has expressed the thought (or hope) that the grace period opens up to embrace accounts, whenever they are earned, if the assignee takes a proper security interest in the underlying contract rights before, or within 45 days of, the tax lien filing. His suggestion rests, of course, on the state-law conception of a "future account" as a presently existing contract right, for which he properly cites Article 9. Unfortunately, it also rests on the federal definition of "commercial financing security," which embraces accounts receivable but not contract rights-unless they are represented by "paper of a kind ordinarily arising in commercial transactions." (For the definition, see INT. REv. CoDE of 1954, \& 6323(c)(2)(C), as added by 80 Stat. 1127 (1966), described in the text accompanying note 82 infra.).

Mr. Plumb writes: "[T]he specific mention of 'contract rights,' as defined in the Commercial Code, among the items which qualify as 'commercial financing security;' suggests that the expected proceeds of an existing executory contract will now be considered as property already 'acquired,' since 'contract rights' by definition are rights 'not yet earned by performance." 22 Bus. LAw. 267, 275 (1967). Tracing this "specific mention" down, one finds in the Committee reports a statement that the term "commercial financing security" includes "paper giving contract rights (as defined in § 9-106 of the Uniform Commercial Code)." H.R. REPORT 42. There is an obvious ellipsis in the argument. Elsewhere Mr. Plumb says only that the legislative history is "encouraging." Williams \& Plumb, The Federal Tax Lien Act of 1966, 44 TAxes 933, 939 (1966). See also Creedon, The Federal Tax Lien Act of 1966, 4 HARv. J. Legrs. 163, 173-74 (1967).

The better basis for the assignee's priority is that his interest in the accounts has the same rank as his interest in the contract rights, and that that would have outranked the $\operatorname{tax}$ lien.

80 INT. REv. CoDe of 1954, § 6323(c)(2)(A), as added by 80 Stat. 1127 (1966).

81 INT. Rev. Code of 1954, \& 6323(c)(2)(C), as added by 80 Stat. 1127 (1966).

82 Concerning "prospective inventory"-state law permitting-the indications are not so clear. See Hogan, Future Goods, Floating Liens, and Foolish Creditors, 17 STAN. L. REv. 822 (1965). 
quired by the taxpayer" before the grace period expires; and we have assumed that it is. Another requirement may be troublesome, however, even if the accounts accrue during the grace period: in order to qualify for priority the security interest must be one "protected under local law against a judgment lien arising, as of the time of tax lien filing, out of an unsecured obligation." 83 The difficulties of interpreting this language have been considered above.

\section{Purchase Money Priority}

A final reference to the Halprin case will expose another incertitude about the tax lien priority. Is there a principle by which a purchasemoney security interest has special standing vis-à-vis the tax lien? It will be recalled that Halprin paid his employees with the funds borrowed from the assignee; this fact impressed the court.

It is eminently appropriate that one who finances propertyproducing transactions be able to look for security to the acquisitions he is making possible. This justifies the common law rule enabling a purchase-money mortgagee, even one with notice, to prevail over the holder of a prior security interest claiming under an after-acquired property clause. . . . The financing of the performance of a manufacturing contract such as we have here is a transaction essentially similar to a purchase-money mortgage; in a real sense, the debt now owed by Doniger was created by funds furnished by Commercial [the assignee finance company]. ${ }^{84}$

In the discussion to follow, we shall see that this reasoning is reflected in the legislative history of section 6323 , but not in the statutory text. In fact, the Act gives grounds for believing that no purchase-money priority now exists-certainly not for a security interest in intangibles.

In priority systems not involving the federal tax lien, it has become settled that purchase-money security interests have precedence over others. ${ }^{85}$ Stated in this broad way, the principle has a touch of novelty about it, for the expression "purchase-money security interest" did not have wide currency before the drafting of the Uniform Commercial Code, at least in relation to personal property. ${ }^{86}$ Yet it was deeply embedded in pre-Code law, where it was customarily indexed under headings such as Conditional Sale and Trust Receipt. Formerly, when the

83 INT. Rev. CoDe of 1954, § 6323(c)(1)(B), as added by 80 Stat. 1127 (1966).

84 In re Halprin, 280 F.2d 407, 410 (3d Cir. 1960).

85 See 2 GiLMore $\S 28$ passim.

86 See 2 Gilmore $\S 29.1$. 
location of title to collateral was a considerable factor in priority problems, and a seller's reservation of title saved him from a competing after-acquired property clause, the principle took poetic form: "like the Borealis Race, Title flits ere you can mark the place."

There is no expression of the principle, poetic or otherwise, in section 6323; does it follow that the tax lien is not subject to the purchasemoney priority? For concrete illustration of the problem, take a dealer in appliances whose inventory is subject to (1) a floating security interest under the Code, and (2) a federal tax lien. The dealer adds a shipment of merchandise to his inventory at a time when both the secured party and the government have filed in the proper way to perfect their interests, and he finances the purchase through a lender who takes trust receipts-the entruster. If the entruster perfects his interest in the new merchandise at the proper time, and takes other cautionary steps, he is assured of priority over the floating lien of the Code; ${ }^{87}$ but what of the tax lien? A possible answer is that he does not have priority because section 6323 does not award it on these facts alone. It is at least an arguable theory that no security interest takes priority over the tax lien except as specified in section 6323-that the statute does not refer by implication to any local law of priority. ${ }^{88}$

Several considerations tend to reinforce this conclusion. First, there was no well-established priority for purchase-money interests over the tax lien under section 6323 prior to the 1966 amendment. ${ }^{89}$ Second, the amendment introduced a priority for claimants like the entruster who meet additional qualifications. In terms of the statute, the new mer-

87 UnIform Commercial Code $\$ \S 9-107,9-312(3)$.

88 Two or three explicit references are made. See subsection $(b)(6)$ and subsection (e), quoted in part in text at note 97 infra.

89 To be sure, an army of precedents can be mustered for the proposition that a debtor's "property" in an item he purchases is a limited one if the seller retains a purchase-money interest in it; and a few of these are tax lien cases. See General Motors Acceptance Corp. v. Wall, 239 F. Supp. 433 (W.D.N.C. 1965), and cases cited; see also Plumb \& Wrigrt 71-72. But the adoption of the Code pushes that concept out of stage center. "Thus the incidents of a security interest which secures the purchase price of goods are the same under this Article [9] whether the secured party appears to have retained title or the debtor appears to have obtained title and then conveyed it or a lien to the secured party." Comment after UNIForm CoMmercial Code \& 9-202; see also UNIFORM COMMERcial CODE § 9-311. In re Halprin announced a much broader purchasemoney priority, of course; see text accompanying note 84 supra.

Sporadically there have been decisions favoring a claimant against the tax lien on general principles of equity. For instance, a taxpayer's legal recovery has slipped through the government's hands when it appeared that otherwise the lawyer who made it possible would go unpaid. See United States v. Kamieniecki, 261 F. Supp. 683 (D.N.D. 1966). Such decisions will be much harder to reach under the new statutory provisions unless they are explicitly dictated; see INT. REv. CODE OF 1954, $\S 6323(\mathrm{~b})(8)$, as added by 80 Stat. 1126 (1966). 
chandise is "commercial financing security"-i.e., inventory-and is therefore "qualified property [to be] covered by . . . a commercial transactions financing agreement." "90 In certain circumstances the tax lien is "not valid" with respect to a security interest in such property coming into existence after notice of the tax lien is filed. There are several explicit qualifications on the "commercial transactions" priority, as it relates to our entruster. ${ }^{91}$ If he does not meet these qualifications, the inference would be that he is not entitled to an implicit priority under the looser conception of "purchase-money." Third, the Code purchasemoney priority is circumscribed by a requirement that the claimant make an early filing, and-in the case of inventory-give timely notification to others who have filed a financing statement covering the inventory. It would be a nice question whether an entruster may, without filing, assert a purchase-money priority over the tax lien. Nothing in local law or in section 6323 speaks directly to the question, and cases might be adduced on either side of it. ${ }^{92} \mathrm{~A}$ decent answer is provided if we say that the entruster may not take priority whether he files or not. These arguments give rather firm support to the conclusion that a lender may not claim a purchase-money priority, as such, as against a tax lien on inventory.

On the other hand, the Senate and House Committee reports accompanying the 1966 amendments broadly support the purchase-money priority:

Although so-called purchase money mortgages are not specifically referred to under present law, it has generally been held that these interests are protected whenever they arise. This is based upon the concept that the taxpayer has acquired property or a right to property only to the extent that the value of the whole property or right exceeds the amount of

90 Subsection (c)(2)(B), (C).

91 Security interest in "qualified property," as defined, with limitations as to (1) time of acquisition; (2) character; (3) whether covered by agreement prior to tax lien filing; (4) security interest protected under local law, as of time of tax lien filing; (5) agreement made in course of financer's trade or business; (6) security acquired in course of taxpayer's trade or business; (7) loan made within 45 days of tax lien filing; (8) loan made before financer had actual notice or knowledge of tax lien filing.

92 See United States v. Lebanon Woolen Mills Corp., 241 F. Supp. 393 (D.N.H. 1965); but see United States v. Creamer Industries, 349 F.2d 625 (5th Cir. 1965), cert. denied, 382 U.S. 957 (1965). Referring to other like cases, Professor Gilmore says that the obvious answer is "No": "Since, as a matter of state law, an unperfected mortgage would lose to any subsequently attaching lien, there seems no reason why it should win over the federal tax lien." 2 GiLMORE $\$ 40.5$, at 1068. But note that a late-filing entruster may pre-empt a "subsequently" attaching lien-UnIform Commercial CODE § 9-301(2). The present question cannot be dismissed quite so simply. See Plumb \& Wright 98, as to the conditional seller, "and perhaps the purchase money mortgagee." 
the purchase money mortgage. This concept is not affected by the bill. ${ }^{93}$

What does this passage signify? Is there a way to reconcile it with the arguments against the entruster stated above? If we say that a purchasemoney priority is maintained for sellers but not for lenders, the remark can be taken as correct without making nonsense of section 6323 . This is the obvious reconciliation, and there is much to be said for it. There will be those who say that a lender financing a purchase ought, in principle, to be treated no less favorably than a financing seller. The purchase-money priority of the Code extends to both, and rightly so; it is a step backward to distinguish in this way; to do so is to exalt form over substance. ${ }^{94}$ So the critic may say. However, there is a rightness in the approach suggested by the Congressional reports that a critic may not notice. The range of cases in which open questions will occur is minimized by confining the purchase-money priority to sellers. The open questions are these: (1) May the claimant assert the priority if he delays-or fails-in perfection of his interest? (2) May he assert the priority if he knew of the tax lien when dealing with the taxpayer? (3) If so, may he assert the priority if he knew of the tax lien filing when dealing with the taxpayer? The author of section 6323 will be faulted for not making a stab at answers to these questions, and it would have been a clear case of faulty drafting, in my judgment, if they were left open for all cases of "purchase-money security" in the Code sense. Yet the drafting is fairly defensible if lenders' claims are ruled out of the priority. It may be that time and litigation will produce more satisfying answers than the draftsman could have done, with respect to sellers' claims.

When a purchase-money priority is claimed over a floating security interest under Article 9, the questions listed above are not open onesat least the Code essays to give clear answers. That fact does not, in it-

93 H.R. REPORT 4. The failure to cover the subject in $\$ 6323$ is the more surprising because of the purported attempt to mesh with the Code; see note 72 supra.

94 UNIFORM COMMERCIAL CODE $\S 9-107$ (b). "The evident intent of paragraph (b) is to free the purchase-money concept from artificial limitations; rigid adherence to particular formalities and sequences should not be required." 2 GILMORE § 29.2, at 782.

If $B$ makes secured advances to the taxpayer that are used to discharge a purchasemoney security interest held by secured party A, B may claim A's priority over a $\operatorname{tax}$ lien, it is said, under any applicable local rule of subrogation. See Plumb \& WRIGHT 74-75, referring to $\S 6323(i)(2)$. But this would not assist a lender (e.g., entruster) financing a purchase. The argument for $B$ is tenuous, and clearly exalts form over substance. Is national uniformity of tax lien priority rules of so little moment as this? See United States v. Speers, 382 U.S. 266 (1965).

Messrs. Plumb and Wright seem doubtful that a purchase-money interest in intangibles has priority. Plumb \& Wright 87. 
self, mean that the tax lien statute must contain clear answers to the analogous problems it raises. Two observations about the scheme of the Code will help sustain a difference in treatment. First, it contains concrete provisions (even if they are ambiguous ones) about the remedies of a defrauded seller. He may reclaim goods obtained upon misrepresentation, and sometimes in the absence of positive misrepresentation, except as the right is limited by the statute. ${ }^{95}$ By contrast, the seller's right of reclamation against the tax lien is an uncertain quantity, if it exists at all, and the courts remain its sole custodian. Hence it is the less surprising for the tax lien statute to be silent about the (seller's) purchase-money priority. A second observation has to do with the scope of the Code definition of purchase-money security interest. Authorities on Article 9 are in some doubt whether or not an interest in intangible property can qualify as a purchase-money interest. ${ }^{96}$ This being the case, a federal priority for lenders, as against the tax lien, would open an additional area of incertitude. Again, the draftsman of section 6323 may have made a canny choice in refusing to specify the details of a purchase-money priority.

\section{Bankruptcy and the Tax Lien}

The language of subordination, of priority, and of ranking, which has been used in various places herein, has been used advisedly. A reference back to the parts of section 6323 that I have quoted will show that this is not the terminology of the statute; rather, it persistently says that the lien shall not be valid with respect to thus-and-so. This phrasing comes from the precursor of section 6323 , as it was originally enacted, and it should not be given more weight than history gives it. One of the new subsections introduces the word "priority," and the way it is used shows that the term "not valid," as applied to the tax lien, means simply that it is subordinated to-ranks lower than-the competing interests that the statute favors.

Section 6323(e) Priority of Interest and Expenses.-If the lien imposed by section 6321 is not valid as against a lien or security interest, the priority of such lien or security interest shall extend to-

(1) any interest or carrying charges upon the obligation

95 UnIform Commercial Code $\$ \S 2-702,2-721$. See In re Hayward Woollen Company, 4 CCH Inst. CREdit Gume ๆ 98,114 (D. Mass. 1967).

96 Professor Gilmore sees no reason why it cannot. Others doubt that it can. He believes it is "almost impossible" however "to conceive of a situation, other than the kind which practitioners refer to as 'academic,' in which intangible money claims could ever be made the subject of a purchase-money transaction." 2 GILMORE \& 29.2, at 780. I think the possibility is far from academic; see text at notes 41,84 supra. 
secured, ... to the extent that, under local law, any such item has the same priority as the lien or security interest to which it relates. ${ }^{97}$

The diction of Article 9 of the Uniform Commercial Code is fairly well purged of demonic language about invalidity and voidness, and it is a pity that section 6323 was not recast in terms of priority of interests. The difference it makes is probably slight, however, and chiefly relates to section 70(e) of the Bankruptcy Act, ${ }^{98}$ which embodies the concept of invalidity. The attachment of a tax lien to property of a taxpayer constitutes what the Bankruptcy Act conceives of as a transfer, ${ }^{99}$ and if he later becomes a bankrupt the trustee will commonly challenge the transfer under one of the Bankruptcy Act provisions. Apparently the trustee does not make out a case if he shows only that the lien is subject to subordination by another creditor (actual or imaginary); he must show that it is, at least potentially, invalid as to a creditor. ${ }^{100}$ For this purpose the trustee will find comfort in the diction of section 6323"shall not be valid"-but this is a slight virtue.

Another bankruptcy provision, section $67 \mathrm{c}(1)(\mathrm{B}),{ }^{101}$ also requires coordination with section 6323. It speaks of statutory liens "required by applicable lien law to be perfected in order to be valid against a

97 Among the items mentioned in this subsection is (5) the "reasonable cost" of credit insurance. Apparently the draftsman dreamt of a local law giving the "same priority" (P) to this cast "as the lien or security interest to which it relates." Parts of this subsection exhibit an element of fantasy.

98 I1 U.S.C. $\$ 110(\mathrm{e})$.

99 Section $1(30)$; 11 U.S.C. $\$ I(30)$.

100 This matter is somewhat controversial. Professor Gilmore indicates that the competing, actual creditors under $\S 70 \mathrm{e}$ must have claims " 'provable under this Act," which means, among other things, that they must be unsecured. . . " 2 GILMORE $\$ 45.3$, at 1289. Professor Riesenfeld, however, takes Gilmore to task for making a "bad blunder" here: "He confuses-unpardonably-provability and allowability. A contract creditor who succeeds in squeezing in an attachment lien under section 9-301(1)(b) or (2) [of the Code] will supply the trustee with Moore $v$. Bay powers. Although the creditor is secured and his claim is not allowable, it is a provable claim as required by section 70e of the Bankruptcy Act." Book Review, 54 CaLIF. L. Rev. 1854, 1857 (1966).

Perhaps it is possible, notwithstanding Professor Riesenfeld, to distinguish the capacity of the creditor qua creditor (having a provable claim) and his capacity qua lienholder. In the Code sections cited, it is said that certain transfers are subordinate to the rights of a person who becomes a lien creditor (with qualifications), and suggested that these rights are outranked in priority by certain transfers. Arguably, at least, Professor Gilmore is right in the sense that the rights of an actual, secured creditor as such do not supply the trustee with 70e-Moore $v$. Bay-powers. "If the right to avoid belongs to the secured creditor as such, there is no way that the trustee in bankruptcy can take it away from him or use it to the disadvantage of the transferee." MAcLAchlan, BankRuPtcy 335 (1956). Cf. Britt v. Damson, 334 F.2d 896 (9th Cir. 1964), cert. denied, 379 U.S. 966 (1965); Dabney v. Chase National Bank, 201 F.2d 635 (2d Cir. 1953), cert. dismissed, 346 U.S. 863 (1953). 101 I1 U.S.C. \& 107(c)(1)(B). 
subsequent bona fide purchaser." Obviously, section 6323(a) is such an applicable law, since it makes the tax lien (until filing) not valid as against any purchaser. Problems abound, however, in connection with other subsections of 6323. Section $67 \mathrm{c}(1)(\mathrm{B})$ provides, with some exceptions, that "every statutory lien which is not perfected or enforceable at the date of bankruptcy against one acquiring the rights of a bona fide purchaser from the debtor on that date, whether or not such purchaser exists," shall be "invalid against the trustee." We have noted that under subsection (c) a finance company will oust the tax lien even after filing by purchasing accounts receivable in certain circumstances. ${ }^{102}$ Is this the hypothetical bona fide purchaser envisaged in section $67 \mathrm{c}$ of the Bankruptcy Act? If so, the government will regularly be bilked of the taxpayer's accounts arising within forty-five days of his bankruptcy. There are at least three interesting counter-arguments that government counsel might make. First, the finance company does not oust the tax lien unless it had a written agreement to purchase (or lend against) commercial financing security before the tax lien filing. The bankruptcy imago "subsequent purchaser" may be thought of as being more in the nature of a casual purchaser from the taxpayer. Second, the finance company does not oust the tax lien unless it meets the test of comparative diligence laid down in section 6323 under the rubric "protected under local law." It may be that a statutory lien must be more vulnerable than this to purchasers in order to fit the bankruptcy description, "not perfected or enforceable ... against one acquiring the rights of a bona fide purchaser." Third, there is a statutory fiction in section 6323 (c)(2)(D) that if the finance company is favored by reason of having made an agreement to purchase accounts receivable, it "shall be treated as having acquired a security interest in commercial financing security." The question is, shall it be treated as not being a hypothetical purchaser within the meaning of section $67 \mathrm{c}(\mathrm{I})(\mathrm{B})$ ?

The first of these arguments appears to be the best. It says, in short, that the bankruptcy trustee ought to derive no advantage from a lien law designed to adjust priorities as between two floating liens on the same fluctuating mass of assets-and that is the object of the provisions in section 6323 about commercial transactions financing. The draftsman was aware that the regular purchasing of accounts ("factoring") is functionally similar to financing against accounts ("lending"), and he sought to equate the two practices in the tax lien statutes, ${ }^{103}$ some-

102 See subsection (c)(2)(A)(ii), set out in note 61 supra.

103 "Generally, section 6323(c) only applies to security interests. Your committee believes it desirable that persons (such as commercial factors) who have agreements to purchase commercial financing security (other than inventory) should be treated in the same manner as persons who acquire security interests in such security." H.R. REPORT 42. 
what in the same way that the Uniform Commercial Code equates them. ${ }^{104}$ The statutory fiction he adopted is nothing more than an artifice for avoiding repetitive clauses in the statute. If this is an accurate projection of the legislative intent, the third argument mentioned above must be discounted.

\section{SURETY AGREEMENTS}

Section 6323 contains two "special rules" for surety agreements, located at subsection (c)(4)(C). ${ }^{105}$ The rules are in the form of definitions of the term "qualified property." In effect, they partially release the surety from the necessity of showing that his collateral was either subject to the tax lien at the time of tax lien filing or directly traceable to his disbursements. However, the property affected by the rules is only (i) proceeds of the contract the performance of which was ensured, and (ii) in case of a building contractor's bond, tangible personal property used by the taxpayer in performance of the building contract. (This should probably be understood to mean only property of the taxpayer.)

Unfortunately, the existence of these special rules may tend to mislead counsel for surety companies into a false sense of security. They have no application except in relation to a security interest described in subsection (c)(l); and such an interest outranks the tax lien only if it is "protected under local law against a judgment lien arising, as of the time of tax lien filing, out of an unsecured obligation." We have spoken of this requirement as amounting to a comparative-diligence rule. Evidently a surety company operating under the Code must file a financing statement prior to the tax lien filing, in order to meet this requirement (and of course include the usual assignment and lien provisions in its agreement with the builder). If advised by alert counsel, the company will consider making a filing for reasons other than the tax lien threat. However, the course of recent decisions indicates that the other reasons are not very pressing; ${ }^{106}$ and until there is some

104 See 1 GiLMORE $\$ 10.5$.

105 INT. REv. CODE of 1954, § 6323(c)(4)(C), as added by 80 Stat. 1128 (1966):

(C) SPECIAL RULES FOR SURETY AGREEMENTS,-Where the obligatory disbursement agreement is an agreement ensuring the performance of a contract between the taxpayer and another person-

(i) the term 'qualified property' shall be treated as also including the proceeds of the contract the performance of which was ensured, and

(ii) if the contract the performance of which was ensured was a contract to construct or improve real property, to produce goods, or to furnish services, the term 'qualified property' shall be treated as also including any tangible personal property used by the taxpayer in the performance of such ensured contract.

106 Pearlman v. Reliance Ins. Co., 371 U.S. 132 (1962); Jacobs v. Northeastern Corp., 416 Pa. 417, 206 A.2d 49 (1965). 
publicized episode of loss to a surety company, loose practice with respect to filing may continue.

\section{Subrogation}

In the recent decisions referred to, surety companies have prevailed against other creditors of their principals on the theory of subrogation, and in section 6323 we find another "special rule" on that subject:

Where, under local law, one person is subrogated to the rights of another with respect to a lien or interest, such person shall be subrogated to such rights for purposes of any lien imposed by section 6321 or $6324 .{ }^{107}$

This rule also contains seeds of deception. It will, of course, permit a surety company very often to take the stance of the laborers and materialmen whose claims are paid under the bond, vis-à-vis the tax lien. This is a prime advantage with respect to mechanic's liens arising prior to the tax lien filing, but so far as concerns mechanic's liens arising thereafter it is no substantial advantage. Does a mechanic's lien "arise," for this purpose, in bits and pieces, as labor and materials are from time to time supplied? Or does it arise when the "mechanic" first gives credit, and fluctuate in amount thereafter? The answer to this question-plainly a critical one-is perhaps indicated in the statutory definition of "mechanic's lienor," but not with ringing clarity. ${ }^{108}$

Subrogation to other interests may be even more a promise made to the ear and broken to the heart. Take, for example, a bank's irrevocable letter of credit as an example of an "obligatory disbursement agreement" - an example given in the legislative history. ${ }^{109}$ If the bank, after the tax lien filing, honors a credit opened by the taxpayer, it may have priority for a security agreement entered into before the filing. Commonly the property subject to the agreement will be goods the acquisition of which is "directly traceable" to the bank's payment, and that will satisfy section $6323(\mathrm{c})(4)(\mathrm{B}) .{ }^{110}$ But how does the bank stand if there is no such prior agreement, and the tax lien is filed before the taxpayer acquires an interest in the goods? The unpaid seller has something in the nature of a security interest until as late as receipt of the goods by the taxpayer: a right of "stoppage of delivery in transit

107 INT. Rev. Code of 1954, § 6323(i)(2), as added by 80 Stat. 1131 (1966).

108 See note 27 supra. The tax lien is "not valid," even though filed, against certain mechanic's lienors. These must necessarily be holders of small claims, because of limitations imposed in subsection (b)(7): “. . . personal residence . . . only if the contract price on the contract with the owner is not more than $\$ 1000 . "$

109 See note 39 supra.

110 See note 38 supra. 
or otherwise."111 Common sense dictates-whether the statutes do or not-that this right prevails over the tax lien, whenever the government files. But when the bank pays the seller, the government might argue, it acquires a security interest subordinate to the tax lien. Not having a security agreement with its customer, the bank might even be held to lack a "security interest": "The term 'security interest' means any interest in property acquired by contract for the purpose of securing payment . . . or indemnifying against loss. . . ."112 Ultimately, it may be, the bank is thrown back on the theory that it is subrogated to the rights of the unpaid seller. For the bank to prevail on this ground would be a worthy result; but there will be much technical difficulty, to say the least, in documenting "under local law" its position as subrogee. The Uniform Commercial Code purports, in section 2-707, to confer an independent security interest in the bank, sub nomine "person in the position of a seller." Does that expression signify subrogation? Of course, an alternative argument for the bank is that it holds the equivalent of a "purchase-money mortgage," the pre-eminence of which is said not to be affected by the tax lien act, as we have seen. As explained above, ${ }^{113}$ however, there is good reason to doubt that a financing bank shares this pre-eminence (if it exists) with a financing seller.

Most likely the bank we have been hypothesizing will, upon paying the seller, have taken in pledge a negotiable document of title covering the goods. In itself, that fact does not ease the bank's worries. A negotiable document of title does not qualify as a "security" under section 6323.114 In subsection $(b)(1)$ there is protection against tax liens for the purchaser or pledgee of a security (e.g., negotiable instrument), and it seems that the 1966 amendment missed an opportunity to extend comparable protection to persons dealing in documents of title. That would be a wholesome extension, at least as to persons who acquire documentary interests in the ordinary course of business.

Finally, it is necessary to enter an additional caveat: probably there is a "federal perimeter" around permissible local concepts of subrogation. Would it be permissible, for instance, to "subrogate" a financer to a mechanic's lien even if the lien were satisfied out of advances by a different financer? ${ }^{115}$ If so, then it would seem that a coach and four can be driven through the tax lien statutes.

\footnotetext{
111 UnizorM COMMERCIAL CODE \$ 2-705.

112 INr. REv. Code of 1954, \& 6323(h)(1), as added by 80 Stat. 1130 (1966). The text of this section is set out at note 60 supra.

113 See text following note 93 supra.

114 INT. Rev. CoDe of 1954, § 6323(h)(4), as added by 80 Stat. 1130 (1966).

116 See Parlane Sportswear Co. v. United States, 359 F.2d 974 (1st Cir. 1966). Parlane
} 


\section{"SUPERPRIORITLES"}

The "securities" provision is one of ten parts of section $6323(\mathrm{~b})$ that are described in the Senate and House Committee reports as creating "superpriorities." They are a random lot, based on a variety of considerations. As to some of them the argument is advanced that the government will suffer no material loss by subjecting the tax lien to displacement, in favor of the claimants concerned. One claimant who is favored is a purchaser "in a casual sale for less than $\$ 250$ " of household goods and the like. ${ }^{116} \mathrm{He}$ must be without knowledge of the lien, and without knowledge that this sale is one of a series of sales. ${ }^{117}$ The concession is a grudging one: apparently it would not protect purchasers of knickknacks at a "barn" auction. (Nor would they be protected, commonly, by the superpriority for retail purchasers of personal property. $)^{118}$ The explanation given in the reports includes the remark, "Your committee has been informed that, as a practical matter, the Internal Revenue Service rarely proceeds against the purchaser unless the item involved has substantial value."119 It is hard to see why the government should not be willing to grant superpriorities shaped more nearly like the Code protection of buyers of consumer goods, as stated in UCC 9-307.

A comparable argument is made on behalf of a superpriority that extends to local liens for real property taxes and special assessments. ${ }^{120}$ In this connection the argument is fallacious, or at least begs the question. It assumes that Congress would not authorize a tax sale free of these liens. (Concurrently with the amendment of section 6323, Congress amended section 6339 to provide that a tax deed "shall discharge such property from all liens, encumbrances, and titles over which the lien of the United States with respect to which the levy was made had

claimed an interest as "equitable assignee" of (former) claims of the taxpayer's employees. It sought to show that another party (Sherry Hill) was in a position to be subrogated to them. This would certainly not suffice to support Parlane's contest with the tax lien. It did not even suffice that Parlane had a legal relation to Sherry Hill: it was not a debtorcreditor relation.

116 INT. REv. CoDE of 1954, § 6323(b)(4), as added by 80 Stat. 1126 (1966).

117 See Plumb, The New Federal Tax Lien Law, 22 Bus. Law. 271, 288 (1967): “The stated premise on which the restriction is based is that 'the series of sales itself may be an indication that the seller is having credit problems.' More likely it means no more than that someone has died, retired from his trade, been transferred overseas, or remodeled his kitchen." "The limitations of the 'retail sale' and 'casual sale' provisions ... probably will be meaningless because of the administrative burden of pursuing the purchaser in most cases." PLUMB \& WRIGHT 54.

118 INT. Rev. CODE of 1954, $\$ 6323($ b)(3), as added by 80 Stat. 1125 (1966).

119 H.R. REPORT 4-5.

120 INT. Rev. Code of 1954, § 6323(b)(6), as added by 80 Stat. 1126 (1966). See H.R. REPORT 5. 
priority." ${ }^{121}$ A better justification for the priority granted to a local tax lien is that it tends to preclude situations of circularity, wherein the federal lien outranks the local one, and a mortgage subordinate to the local lien outranks the federal one. ${ }^{122}$

The holder of a repairman's lien on personal property is also favored with a superpriority, if he "is, and has been, continuously in possession of such property from the time such lien arose." 123 An argument advanced on his behalf is that "his work can be expected to enhance the value of the property by his labor and, as a result, the value of the Federal tax lien." 124 The same argument is advanced on behalf of certain mechanic's liens and attorneys' liens. ${ }^{125}$ However, the draftsman did not place any great weight on it, evidently, for he confined these priorities to groups whose interest (it may fairly be assumed) lie close to the congressional heart. In part, of course, the restrictions reflect a judgment that some persons cannot reasonably be expected to search for tax lien filings; ${ }^{126}$ but in part also these superpriorities are (not to put too fine a point upon the matter) simply class legislation. ${ }^{127}$

Two other transactions protected by superpriorities are life insurance policy loans (including a special provision for automatic premium loans) granted by the insurer, ${ }^{128}$ and passbook loans granted by the issuer. ${ }^{229}$ The notable feature of these provisions is that the draftsman acceded to the theory of some courts that there is a loan in these situations, and that the taxpayer's contractual interest constitutes collateral. In the interest of elegance in the law, to say the least, he might better have based himself on the theory that, in substance, the taxpayer, or "borrower," is only exercising his contract privilege of advancing the maturity of his rights against the "lender," or a portion of them. ${ }^{130}$

121 INT. REv. CODE of 1954, $\$ 6339$ (c), as added by 80 stat. 1137 (1966).

122 The priority is cognate to subsection (e)(6).

123 INr. REv. CoDe of 1954, § 6323(b)(5), as added by 80 Stat. 1126 (1966).

124 H.R. REPORT 5.

125 INT. REv. CODE of 1954, $\$ 6323(\mathrm{~b})(7)-(8)$, as added by 80 Stat. 1126 (1966). See H.R.

REPORT 6.

126 Ibid.

127 See Plumb, The New Federal Tax Lien Law, 22 Bus. LAw. 271, 285 (1967): In relation to mechanic's liens-subsection (b)(7)-“"the law proceeds to impose some of the petty and irrational restrictions which are typical of a number of the new provisions." "As usual, Congress took care of the farmer ...."Williams \& Plumb, The Federal Tax Lien Act of 1966, 44 TAXEs 933, 941 (1966).

128 INT. Rev. Cone of 1954, § 6323(b)(9), as added by 80 Stat. 1126 (1966). See Creedon, The Federal Tax Lien Act of 1966, 4 HARv. J. Lecis. 163, 184-88 (1967).

129 INT. Rev. Code of 1954, $\$ 6323(b)(10)$, as added by 80 Stat. 1127 (1966).

130 See United States v. Home Life Ins. Co., 355 F.2d 86 (2d Cir. 1966); United States v. Sullivan, 333 F.2d 100 (3d Cir. 1964). For the view that a "banker's lien" is not a lien 


\section{ConCLuSION}

Section 6323 is not exactly a statute that he who runs may read. Some parts of it may be read in different ways, more or less equally plausible; and there are no doubt countless ways of misreading it. In a way it puts one in mind of a Victorian, or perhaps a gothic building, all decked out with furbelows and crenellations, so much so that the structural elements are hard to discern. On the other hand, some of its language (e.g., "commercial transactions financing agreement") might be found in the syllabus for a futuristic law school course. Many of its peculiarities can be accounted for by the fact that it makes room, quite properly, for a variety of state policy choices, as indicated by its repeated references to "local law." I have tried to show that these references are not exhaustive, by any means, and that local law will control many a tax lien problem at points where section 6323 does not invoke it explicitly.

Particularly in characterizing "security interests" section 6323 fails to take a clear stand on some fundamental issues. If an item of collateral is exchanged for another, for instance, does the security interest (covering proceeds) follow into the new item, or is the time seized anew by the security agreement? And if successive advances are made against the same collateral under the same security agreement, are there successive security interests? The Uniform Commercial Code throws considerable light on these questions (although there are obscurities enough), but we cannot be sure that local law is decisive in a tax lien case. This is one of the chief defects in section 6323: it suggests that these questions have federal answers; but one ransacks it in vain to find them.

Section 6323, as amended, is in some respects an artless statute, although it is equipped with many an artifice. Recognizing this, the courts should give rein, I think, to their sense of the reason and purpose of the act in cases where the letter of it would give serious offense. In part, at least, Congress was motivated by a spirit of magnanimity toward private interests when it rewrote the section. We may hope that the courts will be similarly moved as they face the formidable task of applying and rationalizing this elaborate statute.

at all, see 1 Gilmore $\$ 10.7$, at 315-16. As to set-off and the tax lien, see Plumb \& WRight 121-25. 